\title{
Gode erfaringer med fleksible studietilbud
}

Mange sykepleierstudenter er fornøyde med nettbasert utdanning, men trenger samlinger og samvær med medstudenter for ikke å bli ensomme.

\section{Forfattere}

\section{Karen Irene Lysberg}

Universitetslektor

Institutt for samfunnsmedisin og sykepleie, NTNU

\section{Ida Eggen}

Høgskolelektor

Høgskolen i Innlandet

\section{Bengt G. Eriksson}

Professor i psykisk helsearbeid

Høgskolen i Innlandet

\section{Nøkkelord}

Sykepleierstudent Desentralisert sykepleierutdanning Nettstudie

Sykepleien 2017 105(7)(60-63)

DOI: https://doi.org/10.4220/Sykepleiens.2017.62477

HOVEDBUDSKAP

Sykepleierstudenter som gjennomførte nett- og samlingsbasert sykepleierutdanning, erfarte bedre selvtillit og mestring knyttet til læringsplattform og nettforelesninger, arbeidskrav og samarbeid med andre. De som fulgte nettforelesningene alene, uttrykte at de følte seg ensomme og isolerte. Samlinger på campus ga fellesskap som styrket studentrollen. Imidlertid kunne studentrollen føles fjern i perioder mellom samlingene. 
I denne artikkelen setter vi søkelyset

på sykepleiestudenters erfaringer med gjennomførte pedagogiske metoder i nett- og samlingsbasert deltidsutdanning i sykepleie. Vi hadde ansvaret for å gjennomføre prosjektet og evaluere det i de to første årene. Sammenlikning av våre funn i studien med tidligere forskning (3, 5-7) bygger opp om at studenter i fleksible studier opplever tilfredshet, motivasjon, nærvær og støtte, men også ensomhet.

\section{Samfunnsoppdrag}

$\AA$ tilby kunnskap og kompetanse i et livslangt læringsperspektiv omtales i høyere utdanning som et samfunnsoppdrag (1-3). Samfunnsoppdraget aktualiserer kunnskap og tilrettelegging av utdanningstilbud, også fleksible utdanningstilbud. Hensikten med fleksibel sykepleierutdanning var å møte samfunnsoppdraget, legge til rette for økt studentgjennomstrømming og økt studenttilfredshet. 23 av 28 studenter fullførte studiet innen tre og et halvt år. Studentene hadde en gjennomsnittsalder på 33 år, og alle hadde tidligere arbeidserfaring. To av studentene var menn.

Et satsingsområde ved fleksible studier har vært å utvikle teknologi knyttet til studier og fokusere mindre på studenterfaringer (3, 4). En doktoravhandling (5) viste at den største fordelen med fleksibel utdanning var muligheten for fleksibilitet. Ulempen var mangel på personlig kontakt, relasjoner, gruppeprosesser og gruppedynamikk i utdanningsprogrammet.

Opplevelsen av ensomhet hos studenter som deltar i nettstudier, er også beskrevet (6), mens betydningen av sosial støtte er vesentlig for tilfredshet og læringsutbytte hos sykepleierstudenter i en nettbasert utdanning (7). 
De pedagogiske metodene som ble anvendt i løpet av de to første studieårene, var kommunikasjon mellom studenter og lærere på læringsplattformen Fronter, nettforelesninger, innlevering av skriftlige obligatoriske arbeidskrav samt samarbeid og deltakelse i samlinger på studiestedet. Vi anvendte nettforelesninger med opptak av ordinære forelesninger laget for studenter i ordinært studieforløp. Videre tok vi i bruk forelesninger av kortere varighet på cirka 10-20 minutter laget spesielt for disse studentene.

\section{Sosial læring}

I vårt studietilbud hadde samarbeidslæring knyttet til kommunikasjon på læringsplattformen og i samlinger, en sentral plass i studiet. Inspirert av Vygotsky (8) utviklet vi bevissthet om at den viktigste læringsstøtten er sosial samhandling. Det vil si at kunnskap først dannes sosialt. Deretter «flyttes den inn» på det indre mentale planet med bånd mellom det mentale, det sosiale og det kulturelle planet.

Samarbeidslæring kan forstås som utveksling av intellektuell kunnskap, erfaringer, forståelser, refleksjoner og utøving av praktiske ferdigheter i et læringsfellesskap (8). Utvekslingen foregår ved hjelp av fysiske og intellektuelle redskaper. Språket har en helt spesiell plass som redskap for sosial utveksling. Lave og Wenger (9) beskriver hvordan praksisfellesskapet er en arena for læring i samarbeid med andre. For eksempel foregikk fire av totalt ni eksamener ved vårt nett- og samlingsbaserte studium i grupper hvor studentene blant annet ble vurdert etter hvilken grad de brukte fagspråk i kommunikasjonen med hverandre. 
Nett- og samlingsbaserte studier utfordrer studentenes evne til å styre sin egen tid fordi tiden til skolearbeid konkurrerer med mange andre plikter $(3,10)$. Vi ønsket derfor at studentene skulle fortelle oss om utfordringen med å utnytte tiden i kampen med andre gjøremål. Vi ville også høre hvordan de erfarte samarbeidet med medstudenter og lærere, både fordeler og ulemper. Studentrollen i studentenes hverdagskontekst er mer eller mindre usynlig (2), også for studentene selv.

\section{三 «Medstudenter er et viktig element i det sosiale støttesystemet.»}

Vi kan si at når studentene er inne på samlinger, styrkes studenten i studentrollen. Gjennom samlinger blir studentene kjent med hverandre og blir en del av det sosiale fellesskapet. Medstudenter er et viktig element i det sosiale støttesystemet; samværet betyr mye for motivasjonen til å fortsette studiet (11). Ved det nett- og samlingsbaserte deltidsstudiet i sykepleie var samlingene på tre til fire dager, én til fire ganger i semesteret. På samlingene prioriterte vi ferdighetstreninger i grunnleggende sykepleie, dialog og refleksjoner med studentene som var samlet i klasserommet.

\section{Metode}


Studien vår er en evalueringsstudie for å se om hvorvidt mål som var satt opp i forkant, er blitt innfridd eller ikke. Studien har et kvalitativt deskriptivt design. Vi samlet inn data gjennom et flerstegs fokusgruppeintervju. Åtte studenter ble tilfeldig trukket ut ved loddtrekning og samtykket til deltakelse. Intervjuspørsmålene fokuserte på motivasjon, samarbeidslæring og ressursstyring. Intervjuguiden tok utgangspunkt i Duncan og McKeachies (12) intervjuskjema «Motivated Strategies for Learning Questionnaire» (MSLQ). Vi analyserte teksten ved å bruke kvalitativ innholdsanalyse, der vi fokuserte på å identifisere meningsbærende enheter, plassere dem i kategorier og analysere med tanke på å finne mønstre relatert til forskningsspørsmålene (13).

\section{Resultater}

Resultatene av evalueringen viste at studentene opplevde meningsfull læring, mestring, optimisme og økt selvtillit ved å bruke den digitale læringsplattformen Fronter. Alle studentene var fornøyde med nettforelesninger, men de som fulgte forelesningene alene, følte seg ensomme og isolerte. De som lyktes med obligatoriske arbeidskrav, fikk styrket stoltheten og selvtilliten. Samarbeid med andre fremmet motivasjon, mening og mestring, mens alenelivet tærte på motivasjonen. Samlingene var en motivasjonsfaktor for studiene. Under samlingene opplevde studentene et fellesskap som virket positivt på studentrollen, som kunne oppleves fjern i perioder mellom møtene på campus.

\section{三 «Samlingene var en motivasjonsfaktor for studiene.»}

Analysen av fokusgruppeintervjuene resulterte i fire kategorier:

1) Å lykkes som student

2) Motivasjon - en kritisk og mangfoldig faktor 
3) Å arbeide alene - en effektivitetsstrategi

4) Samarbeid som læringsstrategi

\section{1) Å lykkes som student}

Fenomenet «å lykkes» er en viktig side ved motivasjon. Begrunnelsen for at vi har skilt det ut som egen kategori, er at studentene understreket betydningen av det å lykkes. Å lykkes betyr å føle seg kompetent, noe som har stor innvirkning på studentenes selvbilde. Det har betydning for synet de har på seg selv og responsen fra folk rundt seg. Positivt selvbilde mener vi har verdi i seg selv uavhengig av motivasjon. En voksen student sier dette:

«Jeg blir veldig skuffa over meg sjøl hvis jeg ikke står, har lagt ned så mye arbeid, tror det har noe med alderen å gjøre. Jeg vet ikke om det stemmer, men jo eldre du blir, desto større er forventningene til deg sjøl. Du er redd for å mislykkes da ...»

Ikke alle studentene følte de fikk støtte fra folk i nærmiljøet. Et preg av jantelov gjorde det ekstra viktig å vise at de klarte studiene:

«Misunnelse fra de andre, de spør om jeg har klart eksamen, ja jeg har jo klart den òg.»

På den andre siden opplevde andre studenter at de fikk støtte fra folk rundt seg. Interessen fra andre kan imidlertid påføre forventninger om at det må gå bra:

«Opplever at folk bryr seg om hva jeg driver med. Får mye positivt tilbake.»

Studentene syntes det var utfordrende å håndtere de tekniske sidene ved læringsplattformen Fronter og bruk av PC. Noen følte seg alene og ensomme:

«Fronter og jeg.»

Andre var stolte av seg selv: 
«Jeg har bestemt meg på forhånd at det er ikke det som skal stoppe meg, jeg fikk jo til det òg. Det er noen terskler og noen sånne bøyger vi må komme over ved å hjelpe hverandre, så går det jo bedre og bedre.»

\section{2) Motivasjon - en kritisk og mangfoldig}

\section{faktor}

En viktig motivasjonsfaktor for ikke å droppe ut av studiet, var utsikten til mer interessante jobber. Denne motivasjonen gjaldt spesielt studenter som hadde lang yrkeserfaring som hjelpepleiere, omsorgsarbeidere og miljøarbeidere. Utdanningen ga mening fordi belønningen ville være ny jobb med mer variasjon, noe vi forstår som en ytre motivasjonskilde. En annen motivasjonsfaktor var ønsket om å lære mer. Også pliktfølelsen ble nevnt som motivasjonsfaktor:

«... Jeg har aldri slutta med noe jeg har begynt med ... må bare tenke framover.»

En velkjent motivasjonsstrategi er å sette delmål. Ved delmål oppfattes ikke målene uoverkommelige, og vi ser større mulighet til å nå målene. Flere studenter var bevisste på denne strategien:

«Viktig å minne oss om å ta bit for bit, ta delmål ... tenker ikke langt fram.»

\section{三 «Flere syntes at alenelivet som student tærte på motivasjonen.»}

Flere syntes at alenelivet som student tærte på motivasjonen. De ønsket støtte fra medstudenter og etterlyste tid på samlingene. Etter hvert i studietiden sank motivasjonen for flere. Studiet hadde ikke lenger nyhetens interesse, og de hadde vært gjennom krevende eksamener og arbeidskrav. Men tanken på nye jobbmuligheter drev mange videre:

«Investering i framtid gjorde at jeg søkte, tenkte at skal jeg gå på skjerma enhet resten av mitt liv?» 


\section{3) $\AA$ arbeide alene - en effektivitetsstrategi}

Noen prioriterte å arbeide alene. Da fikk de ro og muligheten til å konsentrere seg:

«Det er godt å jobbe alene, ingen andre som bestemmer ..., de uendelige diskusjonene att og fram som er hemmende, får ikke utviklet seg sjøl i gruppe, blir overkjørt, folk som kan mer enn deg overkjører deg.»

Tid er en knapphetsressurs studentene hegner om:

«Det er klart at en blir mye alene ... Tre timer om dagen til å kjøre bil, da sitter jeg heller hjemme.»

Det var positivt og motiverende å være selvstyrte, samtidig som det kunne røyne på å være alene med tungt fagstoff. Flere av studentene trakk inn effektiv tidsbruk i argumentene for og imot å arbeide sammen med andre, versus det å arbeide alene.

Å øremerke tid ble oppfattet som positivt fordi det ga god struktur på arbeid, familie, fritid og studier. Noen arbeidet mest hjemme, mens andre erfarte at det var nyttig å møtes i skolens desentrale lokaler.

Det kan være vanskelig å holde drivet oppe over tid. Friheten dette studiet gir, er krevende. Noen syntes det var problematisk å disiplinere seg helt fra starten av studiet:

«Sliter med å strukturere meg i heimen, det er sånn jeg er. Fikser ikke å arbeide to dager i uka med skolearbeid, går til og fra .... alltid dårlig samvittighet.»

Ansvaret for egen læring kan bli mer enn man kan bære, og følelsen av ikke å lykkes kan tære på motivasjonen. Samtidig presser andre plikter på.

\section{4) Samarbeid som læringsstrategi}


I temaet om samarbeid var studentene spesielt

opptatt av samarbeidet for å lykkes med eksamener.

Mange av studentene fortalte om hvordan de sammen

forberedte seg til eksamen. Samarbeidet bidro til

forståelse ved at de hørte og spurte hverandre:

«Det var slik at vi ga hverandre lekser, og så har vi liksom hørt på det og det i nettforelesning.»

Det var ukjent for de fleste av studentene å skrive fagoppgaver. Flere ga uttrykk for usikkerhet og redsel for ikke å lykkes. Mange studenter møttes utenom samlingene for å hjelpe og støtte hverandre:

«.... Vi har nå vært fire stykker som har sittet der og sett på nettforelesninger, ... hver tirsdag og onsdag. Det synes jeg er gull verdt. Jeg tror ikke jeg hadde kommet gjennom studiet hvis jeg skulle studert helt for meg selv i heimen.»

Gjennom samarbeidet opplevde studentene sosial støtte og mestring, som er viktige motivasjonsfaktorer i læringsarbeidet. De fleste studentene syntes samarbeidet var en hensiktsmessig læringsstrategi.

\section{Bruk av Fronter}

I nettbaserte studier er det viktig med ferdigheter $\mathrm{i}$ bruk av PC (14). Vår studie viser at det å bruke Fronter, resulterte i frustrasjon til å begynne med, for deretter å gi stor tilfredshet. Å kunne mestre verktøyet bidro i seg selv til optimisme og tilfredshet. Hjelp fra medstudenter syntes å være gode bidrag til å lykkes med læringsplattformen.

\section{Nettforelesninger}


Nettforelesninger har mange fordeler, og spesielt voksne studenter tiltales av metoden $(5,15,16)$. De undervisningsmetodene som ble brukt, ga studentene fleksibilitet i egen studieaktivitet - når og hvordan de studerte og lærte. Data fra fokusgruppeintervjuene viser at alle studentene var fornøyde med nettforelesningene. Det gjaldt både de som arbeidet alene, og de som satt sammen med medstudenter. En studie (6) viser derimot at studenter som var lite fortrolige med internett, utviklet frustrasjon, isolasjon og ensomhet ved nettforelesninger. I vår studie uttrykte også studentene som fulgte forelesningene alene, at det kunne røyne på med motivasjonen, og at de kjente på isolasjon og ensomhet.

\section{Obligatoriske arbeidskrav}

Studenter i fleksibel sykepleierutdanning foretrekker læring med arbeidskrav $(5,17)$. I intervjuene fortalte studentene at innlevering av obligatorisk arbeid bidro til usikkerhet, men når de lyktes, styrket det stoltheten og selvtilliten. Stoltheten kan spores tilbake til grundig og selvstendig arbeid som forstås som dybdelæring $\mathrm{i}$ motsetning til overflatetilnærming. Eldre studenter har mer tendens til dybdetilnærming enn yngre studenter (18). Studenter som benytter dybdetilnærming, har større indre motivasjon og læringsnysgjerrighet enn studenter som benytter overflatetilnærming (18).

\section{三 «Studenter i fleksibel sykepleierutdanning foretrekker læring med arbeidskrav.»}

Ingen av studentene mente det var for mange obligatoriske arbeidskrav. Obligatoriske arbeidskrav kan være til hjelp for å rydde tid og gi argumenter i hjemlige forhandlinger samt hjelpe studentene med å prioritere (10). At obligatoriske skriftlige arbeider hjelper studentene med å arbeide jevnt og trutt, er en oppfatning vi deler med flere $(2,17)$. Et bidrag til variert læring kan være at studentene er med på å lage tester og oppgaver. 


\section{Samarbeidslæring}

Sammenlikning av våre funn med tidligere forskning (3, 5-7) bygger opp om at studenter i fleksible studier opplever tilfredshet, motivasjon, nærvær og støtte, men også ensomhet. Det er avgjørende med samarbeid og støtte fra nettstudenter, familiemedlemmer, kollegaer og arbeidsgivere for å lykkes med nettstudier (10).

I vår studie har vi vektlagt spesielt samarbeidslæring og samlinger fordi vi har tro på at samarbeid har betydning som støttesystem siden studentene sjelden treffes. I intervjuene ga flere av studentene uttrykk for at det å arbeide og lære sammen, fremmet motivasjon, mening og mestring. Samarbeidet inneholdt informasjon, bekreftelser samt instrumentell og emosjonell støtte som bidro til å dempe usikkerheten mange opplevde i begynnelsen av studiet. Studentene erfarte også negative sider ved å samarbeide, og flere syntes det var en lettelse da de gikk inn i en periode med individuelt arbeid. Tidsbruk kan være avgjørende når fleksible studier blir foretrukket av modne studenter som har knapphet på egen tid $(5,17)$.

Samlinger på skolen er sentralt i et nett- og samlingsbasert studium og har betydning for læring, motivasjon, bevissthet om studentrollen og sosial kontakt (11). I intervjuene sa studentene at samlingene var nødvendige for å motivere seg til studiene. På samlingene erfarte de studentfellesskap og styrking av studentrollen. Studentrollen kunne føles fjern mellom møtene på campus. Personlige kontakter og samlinger reduserer følelsen av isolasjon og ensomhet (6). 
Studenters tilfredshet med samarbeidslæring vil nok aldri være entydig og unisont positiv.

Samarbeidslæring som pedagogisk metode har relativt kort historie i norsk skole, og vi mangler derfor lang erfaring med hvordan vi kan lykkes med metoden. Vi bør derfor arbeide med modeller der vi sikter mot å utnytte positive trekk ved samarbeid, samtidig som vi tilstreber å nedtone slitasje- og konfliktsidene.

\section{Konklusjon}

Studien har vist hvilke erfaringer studentene har med Fronter, nettforelesninger, arbeidskrav og samarbeidslæring. Studentene opplevde mestring og selvtillit knyttet til læringsplattform og nettforelesninger, arbeidskrav og samarbeid med andre. De som fulgte forelesningene alene, følte seg ensomme og isolerte.

Relevante områder for videreutvikling og forskning kan være betydningen av arbeidskravene og samlingene i nett- og samlingsbasert utdanning. Obligatoriske arbeidskrav er viktig for motivasjon og læringsutbytte, noe vi ønsker enda mer kunnskap om. Fordi samarbeid har betydning for læring, bør det arbeides mer med modeller som styrker positive sider ved samarbeidet, og som begrenser uheldige sider som et samarbeid kan gi. Samlinger er til nå viet liten oppmerksomhet og forskerinteresse. Fordi det er en betydelig vekst i antallet nett- og samlingsbaserte studier, er det ønskelig med studier framover om samlingenes innhold og metoder.

\section{Referanser}

1. Grepperud G. «Kunnskap skal styra rike og land ...» - livslang læring i høyere utdanning. Oslo: Gyldendal Akademisk; 2007.

2. Rønning WM. Den usynlige student. Voksne i fleksibel høyere utdanning. Trondheim: Tapir Akademisk forlag; 2007. 
3. Rønning WM. Akademia som læringsarena utfordringer og mestring. En studie av voksne, fleksible studenters bruk av læringsstrategier og tilnærminger til læring i høyere utdanning. (Doktoravhandling). Trondheim: NTNU; 2009.

4. Harrison R, Gemmell I, Reed K. Student satisfaction with a web-based dissertation programme: Findings from an international distance learning master's programme in public health. International Review of Research in Open and Distance Learning 2014;15:182-202.

5. Vecchia ED. The phenomenon of learning: The lived experience of distance education baccalaureate nursing students. (Doktoravhandling). USA: Capella University; 2010.

6. Owens J, Hardcastle LA, Richardson B.

Learning from a distance: The experience of remote students. Journal of Distance Education 2009;23(3):53-74.

7. Cobb SC. Social presence, satisfaction, and perceived learning of RN-to-BSN students in webbased nursing courses. Nursing Education Perspectives 2011;32(2):115-9.

8. Vygotsky L. Mind in Society. Cambridge, MA: Harvard University Press; 1978.

9. Lave J, Wenger E. Practice, person, social world. I: Daniels H (red.). An introduction to Vygotsky. Routledge,Taylor \& Francis Group: London and New York; 1996 (s. 143-150).

10. Nilsen G, Immonen I. Nettstøttet samhandlingslæring-hjelp eller hindring i helsefagutdanninger? Uniped 2013;36(3):77-89.

11. Kreie J, Headrick RW, Steiner R. Using eam learning to improve student retention. S. College Teaching 2007;55:51-6. 
12. Duncan TGD, McKeachie WJ. The making of the motivated strategies for learning questionnaire. Educational Pshycologist 2005;40(2):117-28.

13. Johannessen A, Tufte PA, Christoffersen L. Introduksjon til samfunnsvitenskapelig metode. Oslo: Abstrakt forlag; 2010.

14. Reinckens J, Philipsen N, Murray TL. Nurse practitioner: Is online learning for you? The Journal for Nurse Practitioners-JNP, 2014;10(9):700-5.

15. Pettersen RC. Studenters læring. Om studenter og elevers læringsmønstre: læringstilnærminger, læringsstrategier, læringsstiler. Oslo:

Universitetsforlaget; 2008.

16. Du S, Liu Z, Liu S, Yin H, Xu G, Zhang H, Wang A. Web-based distance learning for nurse education: a systematic review. International Nursing Review 2013;60:167-77.

17. Hyde A, Murray M. Nurses' experiences of distance education programmes. Journal of Advanced Nursing 2005;49(1): 87-95.

18. Ak S. A conceptual analysis on the approaches to learning. Educational Sciences: Theory and Practice 2008;8(3):707-20. 